\title{
Histopathological Alterations in the Kidney Tissue Following Topical Ankaferd Hemostat Application in a Rat Renal Injury Model
}

\author{
Derya KARAKOC ${ }^{1}$, Eylem AKAR ${ }^{2}$, Salih AKSU³ , Aysegul UNER ${ }^{4}$, Arif OZDEMIR', \\ Erhan HAMALOGLU ${ }^{1}$, Ahmet OZENC ${ }^{1}$, Ahmet DOGRUL ${ }^{1}$, Bibihanim MEMEDOVA ${ }^{1}$, \\ Ibrahim C. HAZNEDAROGLU ${ }^{3}$

\footnotetext{
' Hacettepe University Faculty of Medicine, Department of General Surgery, Ankara, TURKEY

${ }^{2}$ Hacettepe University Faculty of Medicine, Department of Pathology, Ankara, TURKEY

${ }^{3}$ Hacettepe University Faculty of Medicine, Department of Hematology, Ankara, TURKEY
} \\ ${ }^{4}$ Hacettepe University Faculty of Medicine, Department of Pathology, Ankara, TURKEY
}

\begin{abstract}
Ankaferd Blood Stopper (ABS) is a novel topical hemostatic agent. ABS has been approved in Turkey for clinical hemorrhages, when the conventional control of bleeding by ligature and/or conventional hemostatic measures is ineffective. ABS has many cellular effects and could modulate numerous hemostatic proteins at the tissue and blood. ABS-induced formation of the protein network with vital erythroid aggregation covers the entire physiological hemostatic process. The aim of this study was to assess histopathological alterations due to topical ABS administration at the renal tissue level. Thirty-six Wistar rats weighing 70 to 80 gm were included into the study. The rats were divided into two groups as "the ABS-applied group" (ABS-G) and "the control group" (C-G). The animals in both groups were then again divided into the three subgroups of "postoperative (Postop.) 60th minutes", "Postop. 48th hours", and "Postop. 15th day". Therefore, there were six rats in each of the subgroups at the end of the analyses. The standard renal injury sites in the rats of ABS-G were applied $2 \mathrm{ml}$. of topical ABS, whereas $2 \mathrm{ml}$. of topical saline was applied to the renal injury sites of the rats in the $\mathrm{C}-\mathrm{G}$ group. We detected significant erythrocyte aggregation and the accumulation of siderophages in the kidney tissue just after 60 minutes of ABS application persisting over 15 days. Our results indicated red blood cell accumulation and siderophages following the use of ABS are compatible with the suggested 'mechanism-of-action' of ABS that ABS-induced formation of the protein network with vital erythroid aggregation covers the entire physiological hemostatic process. Further experimental search is needed to find out the molecules inside the ABS protein library leading to the ABS-induced aggregation at the renal tissue level.
\end{abstract}

Keywords: Ankaferd Blood Stopper, Renal Injury, Erythrocyte Aggregation, Siderophages Accumulation

\section{ÖZET}

Bir Rat renal hasar Modelinde Topikal Ankaferd Hemostat Uygulamasını Takiben Böbrek Dokusunda Gelişen Histopatolojik Değişkenlikler

Ankaferd Blood Stopper (ABS) yeni geliştirilmiş bir topikal hemostatik ajandir. ABS, ülkemizde klasik yöntemlerle durdurulamayan veya bu uygulamaların yetersiz kaldığı klinik kanamaların topikal kontrolünde kullanılmaktadır. ABS çok değişken hücresel etkilere sahip olup dokular ve kandaki pek çok hemostatik molekülü etkilemektedir. ABS tarafından geliştirilen özgül protein ağı, vital eritroid aggregasyona yol açarak tüm fizyolojik hemostatik süreci yönlendirmektedir. 
Bu çalışmanın amacı, böbrek dokusu düzeyinde topikal ABS uygulamasının doğurduğu histopatolojik değişimleri ortaya koymaktır. Otuzaltı Wistar rat (70-80 gram) çalışmaya dahil edilmiştir. Hayvanlar, iki gruba ayrılarak değerlendirilmiştir "ABS-uygulanan grup" (ABS-G) ve "kontrol grubu" (C-G). Sonrasında da deney hayvanları üç alt gruba ayrılarak karşılaştırılmışlardır; "postoperatif (Postop.) 60. dakika", "Postop. 48. saat”, ve "Postop. 15. gün”. Sonuçta her alt grupta analiz için altı rat olacak şekilde araştırma kurulmuş oldu. ABS-G grubu ratlarda standart renal hasar bölgelerine $2 \mathrm{ml}$. topikal ABS uygulandı. Kontrol grubundaki hayvanlarda da aynı renal lezyonun oluşturulmasını takiben $2 \mathrm{ml}$. salin topikal uygulandı. ABS uygulanan grupta histopatolojik incelemelerde 60 dakika sonrasında ortaya çıkan ve 15 gün boyunca devam eden renal lezyon bölgesinde belirgin eritrosit aggregasyonu ve siderofaj akümülasyonu tespit edildi. Bu bulgular renal doku düzeyinde daha önce kanda tanımlanmış ABS hemostatik mekanizmasının geçerliliğini göstermektedir. ABS, proteomik içeriğiyle dokuda da eritrosit aggregasyonuna ve siderofaj birikimine yol açarak fizyolojik hemostaza hizmet etmektedir. Sonraki deneysel çalışmalar ABS protein kütüphanesi içerisinde bulunan moleküllerin renal doku düzeyindeki etkilerinin araştırıması üzerine düzenlenmelidir.

Anahtar Kelimeler: Ankaferd Blood Stopper, Renal hasar, Eritrosit Aggregasyonu, Siderofaj birikimi

\section{INTRODUCTION}

Ankaferd Blood Stopper (ABS), a novel topical hemostatic agent, has been approved in Turkey for clinical hemorrhages, when the conventional control of bleeding by ligature and/or conventional hemostatic measures is ineffective. ${ }^{1} \mathrm{ABS}$ is clinically effective in bleeding individuals with normal hemostatic parameters and in patients with deficient primary hemostasis and/or secondary hemostasis..$^{1-3}$ ABS-induced formation of the protein network with vital erythroid aggregation covers the entire physiological hemostatic process. Mainly, there are distinct important components of the ABS-induced hemostatic network. Vital erythroid aggregation takes place with the spectrin, ankrin and actin receptors on the surface of red blood cells. Those proteins and the required ATP bioenergy are included in the ABS protein library. ${ }^{46}$ Ankaferd also upregulates GATA/FOG transcription system affecting erythroid functions. Urotensin II is also an essential component of Ankaferd and represents the link between injured vascular endothelium, adhesive proteins, and active erythroid cells. Those concepts have been developed via MALDI-TOF proteomic molecular analyses, cytometric arrays, transciption analysis, and SEM ultrastructural examinations as well as numerous investigations interacting with in vitro and in vivo research settings..$^{1,-8}$

ABS has many cellular effects. ABS has been shown to affect renal tubular apoptosis based on the level of hemorrhage. ${ }^{9}$ When the bleeding associated with the surgery of partial nephrectomy is mild or moderate, ABS can initially increase renal tubular apoptosis. On the contrary; during the increased amount of massive bleeding from the kidney tissue,
ABS decreases apoptosis in renal tubular cells. Therefore, ABS modulates the cellular apoptotic responses to hemorrhagic stress as well as its hemostatic hemodynamic activity. The finding of ABS-induced thrombin receptor PAR-1 down-regulation gives an additional clue on the possible mechanism of ABS associated apoptosis modulation at the tissue level. ${ }^{10}$ Preliminary findings focusing on in vitro anti-neoplastic effects ${ }^{11,12}$ of ABS also prompt to begin for searching the ABS effects at the cellular level in health and in neoplastic diseases.

ABS has many effects on proteins at the tissue and blood. Dose-dependent reversible PAR-1 down-regulation is mediated by ABS. ABS induced sustained PAR-1 down-regulation in the presence of lipopolysaccharides (LPS). ${ }^{10}$ Those findings are compatible with other investigations focusing on the endothelial hemostatic molecules, EPCR and PAI-1. ${ }^{13}$ ABS had dual diverse dynamic reversible actions on EPCR and PAI-1 inside vascular endothelial cells also in the model of HUVEC. Sudden anti-hemorrhagic efficacy of ABS via immediate enhanced expression of pro-hemostatic PAI-1 and down-regulated anti-coagulant EPCR upon the exposure of ABS..$^{13}$ Those findings indicated that ABS may act as a topical biological response modifier.

Acute mucosal toxicity, hematotoxicity, hepatotoxicity, nephrotoxicity, and biochemical toxicity were not observed during the short-term oral ABS administration in rabbits. ${ }^{14}$ Clinical Phase I study of ABS also disclosed topical and systemic safety of its clinical external application. ${ }^{15}$ However, Turhan el al. suggested hepatic erythrocyte-agglutinating activity of intravenous systemic ABS administrati- 


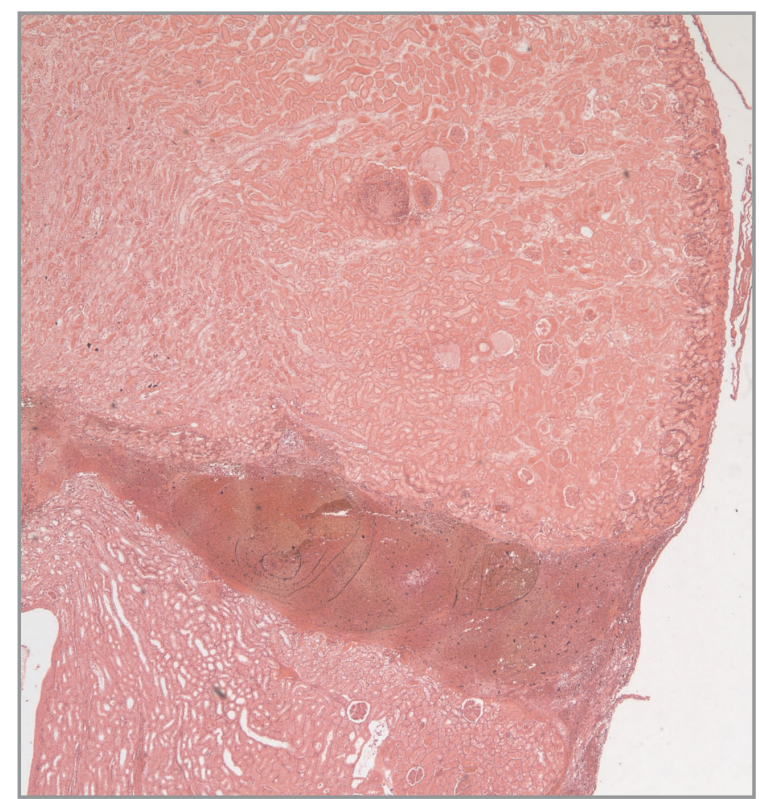

Figure 1. Erythrocyte aggregation in the kidney area where ABS was applied. $H$ \& E, reduced from X40

on. ${ }^{16}$ Moreover, a recent study suggested in vitro ABS cytotoxicity on the human pulp fibroblasts. ${ }^{17}$ Therefore, ABS effects on the tissue level should also be searched after its topical usage in the injury models. The aim of this experimental study was to assess short- and mid-term topical kidney safety following the topical administration of ABS in rats. We intended to analyze histopathological topical tissue effects of ABS administration at the renal tissue level.

\section{MATERIALS AND METHODS}

Thirty-six Wistar rats weighing 70 to $80 \mathrm{gm}$ were included in this study. The study was performed with the approval of Hacettepe University animal research ethical committee. All of the rats were transferred from the hospital animal research center. The rats were housed in stainless steel cages in an animal room maintained at $22^{\circ} \mathrm{C}$ with 12 hours light periods. The rats were divided into two groups as "the ABS-applied group" (ABS-G) and "the control group" (C-G). The animals in both groups were then again divided into the three subgroups of "postoperative (Postop.) 60th minutes", "Postop. 48th hours", and "Postop. 15th day". Therefore, there were six rats in each of the subgroups at the end of the analyses.

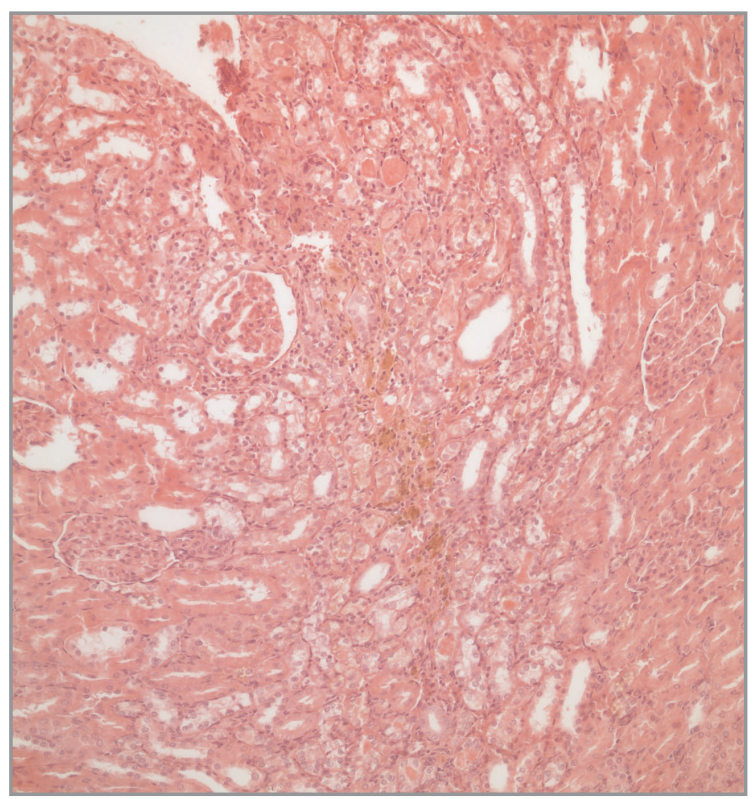

Figure 2. Siderophages in the kidney area where ABS was applied $\mathrm{H}$ \& E, reduced from $X 40$

Intraperitoneal xysilasine $\mathrm{HCl} 5 \mathrm{mg} / \mathrm{kg}$ and ketamine $30 \mathrm{mg} / \mathrm{kg}$ were applied to perform proper anesthesia for all of the animals in the study. After administering prophylactic single dose broad-spec-trum antibiotics a $5 \mathrm{~cm}$. midline incision was made in the abdo-men after sterile preparation and draping. The right kid-ney was completely mobilized. To achieve hilar control the right renal artery and vein were occluded with a Rommel vascular clamp. Standard renal injury in the right kidney was generated between the upper and lower poles of the anterior side of the kidney as a cut of $3 \mathrm{~cm}$ longevity and 2 $\mathrm{cm}$ in depth with a 15 number knife. The renal injury sites in the rats of ABS-G were applied $2 \mathrm{ml}$. of topical ABS, whereas $2 \mathrm{ml}$. of topical saline was applied to the renal injury sites of the rats in the C$\mathrm{G}$ group. After the procedure sponges were used to collect all visible clots and blood, and the kidney was replaced in the renal fossa. The surgeon with an assistant immedi-ately began repair procedures for the abdomen. The rats of the "Postop. 60th minutes" subgroups were followed for 60 minutes and then the kidney was surgically removed for histopathological analyses. The rats of the "Postop. 48th hours" subgroups were followed for 48 hours and then the kidney was surgically removed via re-laparotomy for histopathological analyses. The rats of the "Postop. 15th day" subgroups were followed 
for 15 days and then the kidney was surgically removed via re-laparotomy for histopathological analyses.

Pathological specimens were evaluated with emphasis on the presence or absence of giant cell reaction, acute inflammation, for-eign material reaction, fibrosis, necrosis, erythrocyte aggregation, microvascular proliferation, fibroblastic activation, siderophages, glomerular necrosis and cal-cification (Figure 1 and Figure 2).

Results were analyzed with SPSS ${ }^{\circledR} 12.0$ for Windows ${ }^{\circledR}$. Definitive statistics were determined as the mean $\pm \mathrm{SD}$, minimum, maximum and percent. The Fisher, Kruskal-Wallis and Mann-Whitney U tests were used to evaluate significance among the groups. The post hoc Bonferroni test was also used to correct the significance level in sub-group comparisons. The differences were considered as statistically significant when the $\mathrm{P}$ value was less than 0.05 .

\section{RESULTS}

A total of 36 open standard renal injuries were generated, and significant bleeding was induced in every case. The rats used for this experimental study had similar morphometric characteristics in body and kidney shape. The injured kidney tissues were also similar in size and shape. Most of the animals survived during the operation and postoperative period. Two rats in the C-G were died the first day following the operation, and one rat in the ABS-G was died on the surgery day.

Giant cell reaction, acute inflammation, fibrosis, glomerular necrosis, adhesion, calcification formation, fibroblast activation and microvascular proliferation were not statistically different among the groups $(p>0.05)$. Erythrocyte aggregation and the accumulation of siderophages were significantly higher in the ABS-G in comparison to the C-G group $(p<0.05)$. There was no erythrocyte aggregation in any of the rats of the "Postop. 60th minutes" of C-G group. However, significant erythrocyte aggregation was observed in all of the rats of the "Postop. 60th minutes" of ABS-G group. Likewise, There was no siderophages in any of the rats of the "Postop. 60th minutes" of C-G group; whereas significant accumulation of siderophages was obser- ved in all of the rats of the "Postop. 60th minutes" of ABS-G group. Erythrocyte aggregation and the accumulation of siderophages were persistent and sustained in the "Postop. 48th hours", and "Postop. 15th day" of the animals of ABS-G group (Figure 1 and Figure 2).

\section{DISCUSSION}

In this study, we detected significant erythrocyte aggregation and the accumulation of siderophages in the kidney tissue just after 60 minutes of ABS application persisting over 15 days. Those findings are compatible with the previous studies by Huri et al testing topical ABS in the in the partial nephrectomy and renal trauma models..$^{18-20}$ Essential erythroid proteins (Ankrin recurrent and FYVE bundle containing protein 1, Spectrin alpha, Actin-depolimerisation factor, Actin-depolimerizing factor, LIM bundle and actine binding subunit 1 isoform a, LIM bundle and actine binding subunit 1 isoform $b$, NADP-dependent malic enzyme, NADH dehydrogenase (Ubiquinone) 1 alpha subcomplex, Mitochondrial NADP (+) dependent malic enzyme 3, Ribulose bisphosphatecarbocsilase large chain, Maturase $\mathrm{K}$ ) and the required ATP bioenergy (ATP synthase, ATP synthase beta subunit, ATP synthase alpha subunit, ATP-binding protein $\mathrm{C} 12$, TP synthase $\mathrm{H}+$ transporter protein, ADF, Alpha-1,2glycosyltransferase ALG10-A) are included in the protein library of ABS. ABS also up-regulates GATA/FOG transcription system affecting erythroid functions and urotensin II. ${ }^{4-6}$ Therefore, our results indicating red blood cell accumulation and siderophages following the use of ABS are compatible with the suggested 'mechanism-of-action' of ABS that $\mathrm{ABS}$-induced formation of the protein network with vital erythroid aggregation covers the entire physiological hemostatic process. Further experimental search is needed to find out the molecules inside the ABS protein library leading to the ABSinduced aggregation at the renal tissue level.

ABS has positive effects on early bone healing together with decreasing inflammation and necrosis and increasing new bone formation. ${ }^{21}$ The accumulation of siderophages in the kidney tissue may be a sign of tissue repair in our study. Furthermore, a recent study has demonstrated that adding ABS on the pancreatic fluid produces aggregates of protein 
network resulting in a solid layer over the pancreatic fluid like a frozen gel with important in vitro biochemical alterations. ${ }^{22}$ ABS has also in vitro anti-bacterial effects. Ankaferd, besides its hemostatic activity, may also inhibit the growth of bacteria. ${ }^{23-25}$ Anti-infectious activity of Ankaferd may represent an advantage over its current clinical use, since it inhibits the growth of bacteria in the area used mainly for its hemostatic activity such as traumatic infected wounds. The antimicrobial activity of Ankaferd was tested against many bacterial pathogens. The isolates included A.baumannii, E. coli, K. pneumonia, P. aeruginosa, Enterobacter spp., Stenotrophomonas maltophilia, methicillin resistant coagulase negative Staphylococcus, vancomycin susceptible Enterococcus and vancomycin resistant Enterococcus (VRE). ${ }^{23-25}$ The mechanism of action regarding the anti-infective effects of ABS is currently unknown. Anti-infective actions of ABS may be related to its hemostatic functions acting on PAR-1, EPCR and PAI-1..$^{10,13}$ affecting distinct steps of coagulation and vascular endothelium. The interrelationships between ABS-induced immune system-driven loss of intestinal goblet cells, anti-infective actions of $\mathrm{ABS}$, and its association with hemostatic molecules remain to be elucidated. Based on the results of our present study and the abovementioned findings, next experimental step shall be to test the topical action of ABS in infected renal injury model.

It has been suggested that ABS could act as a topical biological response modifier via demonstrating diverse actions of ABS in the presence of LPS..$^{10,13}$ "LPS challenge" refers to the process of exposing a biological environment to an LPS which may act as a toxin to test immunological and hemostatic responses. LPS application to HUVEC caused ABSinduced additional sustained significant down-regulations in the expressions of PAR-1 mRNA. ${ }^{10}$ Sustained significant PAR-1 down-regulation mediated by ABS in the presence of LPS seems to have a protective role against endothelial injury. Therefore, there are molecular links underlying ABSpleiotropic cellular actions acting on anti-infective, wound healing, and apoptotic processes. . $^{1,6,7,10,13,17,24.32}$ Since renal system is located at the crossroads of cellular neoplastic development and protein secretions, the unique effects of ABS on distinct renal cell types shall be investigated in future in vivo animal models mimicking cancer models. Our present study represent true basis for the design of such experimental animal trials.

ABS has been shown to affect renal tubular apoptosis based on the level of hemorrhage in a previous study. ${ }^{9}$ When the bleeding associated with the surgery of partial nephrectomy is mild or moderate, ABS can initially increase renal tubular apoptosis. On the contrary; during the increased amount of massive bleeding from the kidney tissue, ABS decreases apoptosis in renal tubular cells.' Therefore, ABS modulates the cellular apoptotic responses to hemorrhagic stress as well as its hemostatic hemodynamic activity.

Since ABS is currently being developed in basic and clinical grounds, those novel observations cast future studies focusing on the pleiotropic effects of this unique novel hemostatic agent. ${ }^{33-37}$ Future experimental trials should focus on the in vivo ABS effects on renal disease expression patterns. ABS protein library and its tissue effects seem to be a starting point to begin designing those kinds of investigations in the kidney system.

Controlled clinical studies conducted to evaluate the effectiveness of ABS in distinct states of bleeding disorders documented the safety and efficacy of traditional Ankaferd hemostat in comparison to conventional anti-hemorrhagic medications. ${ }^{38-44}$ The first randomized controlled clinical study was reported in 49 patients with anterior epistaxis. In patients to whom ABS was applied, significant differences in effective control of anterior epistaxis were observed compared to phenylephrine. Similarly, another clinical trial has also demonstrated the effectiveness of ABS in children undergoing tonsillectomy. In this prospective controlled study, the success of ABS and the traditional knot-tie approach to reach hemostasis for patients undergoing tonsillectomy was evaluated. ABS is not only safe and efficient, but also it decreases intra-operative bleeding and reduces operating time compared to the traditional hemostasis methods after cold knife dissection tonsillectomy. The effectiveness of ABS in cancer patients was also reported in a study by $\mathrm{Al}$ et al. ${ }^{2}$ Sixty-nine cancer patients that were admitted for port insertion to a university hospital was randomized either to take a wet compress form of ABS or regular dry sterile sponges to stop the bleeding 
that occurs during the clinically indicated vascular port insertion. The average time needed to stop the bleeding was $32.97 \pm 29.9$ s for ABS group and $123.75 \pm 47.5 \mathrm{~s}$ for dry sponge group. ABS was proven to stop local bleeding in a shorter time, with a lower recurrence rate in comparison with the sterile sponge. ${ }^{2}$ Additional clinical studies about antihemorrhagic efficacy of ABS on the bleeding due to adenoidectomy, the surgical bleeding of thyroidectomy, gastrointestinal bleedings and dental bleedings were performed with similar beneficial outcomes. ${ }^{38-44}$ The findings of our present experimental study represent a starting point to investigate clinical anti-hemorrhagic effects of ABS hemostat.

\section{REFERENCES}

1. Beyazit $Y$, Kurt M, Kekilli M, et al. Evaluation of hemostatic effects of ankaferd as an alternative medicine. Altern Med Rev 15: 329-336, 2010.

2. Al B, Yildirim C, Cavdar M, et al. Effectiveness of Ankaferd blood stopper in the topical control of active bleeding due to cutaneous-subcutaneous incisions. Saudi Med J 30: 1520-1525, 2009.

3. Haznedaroglu BZ, Haznedaroglu IC, Walker SL, et al. Ultrastructural and Morphological Analyses of the In Vitro and In Vivo Hemostatic Effects of Ankaferd Blood Stopper. Clin Appl Thromb Hemostas 16: 446-453, 2010.

4. Demiralp DO, Haznedaroglu IC, Akar N. Functional proteomic analysis of Ankaferd (R) Blood Stopper. Turk J Hematol 27: 70-77, 2010.

5. Haznedaroglu IC. Molecular Basis of the Pleiotropic Effects of Ankaferd Blood Stopper. IUBMB Life 61: 290, 2009.

6. Yılmaz E, Gulec, S, Torun D, Haznedaroglu IC, Akar N. The effects of Ankaferd $囚$ Blood Stopper on transcription factors in HUVEC and erythrocyte protein profile. Turk J Hematol 28: 276-285, 2011.

7. Ak G, Cakir O, Kazancioglu HO, et al. The use of a new hemostatic agent: Ankaferd Blood Stopper in hemophiliacs. Haemophilia 16: 51, 2010.

8. Goker H, Haznedaroglu IC, Ercetin S, et al. Haemostatic actions of the folkloric medicinal plant extract Ankaferd Blood Stopper. J Int Med Res 36: 163-170, 2008.

9. Huri E, Haznedaroglu IC, Akgul T, et al. Biphasic effects of ankaferd blood stopper on renal tubular apoptosis in the rat partial nephrectomy model representing distinct levels of hemorrhage. Saudi Med J 31: 864-868, 2010.
10. Karabiyik A, Gulec, S, Yilmaz, E, Haznedaroglu IC, Akar N. Reversible Protease-Activated Receptor 1 Down-regulation Mediated By Ankaferd Blood Stopper Inducible With Lipopolysaccharides Inside The Human Umbilical Vein Endothelial Cells. Clin Appl Thromb Hemost 17: 165-170, 2011.

11. Goker H, Cetinkaya D, Kilic E, et al. Anti-cancer activity of ankaferd blood stopper on osteosarcom (SAOS2) cell lines in vitro. In: Haznedaroglu I.C. GH, Ozdemir $\mathrm{O}$, Kosar A, Firat H, editor. Ankaferd: Scientific perspectives and basic-clinical data. Istanbul, Naviga Publications, 2008: 109.

12. Goker H, Kilic E, Cetinkaya D, et al. Anti-cancer activity of Ankaferd on human colon cancer (CACO-2) in vitro. In: Haznedaroglu IC, Goker H, Ozdemir O, et al., editors. Ankaferd: Scientific Perspectives and BasicClinical Data. Istanbul, Naviga Publications, 2008: 108.

13. Karabiyik A, YIImaz E, Gulec S, Haznedaroglu IC, Akar $N$. Dual diverse dynamic reversible actions of Ankaferd on EPCR and PAI-1 inside vascular endothelial cells with and without LPS. Turk $J$ Hematol. doi: 10.5152/tjh.2011.41, 2012.

14. Bilgili H, Captug $O$, Kosar A, et al. Oral Systemic Administration of Ankaferd Blood Stopper Has No Short-Term Toxicity in an In Vivo Rabbit Experimental Model. Clin Appl Thromb Hemostas 16: 533-536, 2010.

15. Balcik OS, Koroglu M, Cipil H, et al. A Placebo-Controlled, Randomized, Double-Blinded, Cross-Over Phase I Clinical Study to Demonstrate Safety of Ankaferd Blood Stopper Topical Usage In Healthy Volunteers. UHOD. doi: 10.4999/uhod.10124.

16. Turhan N, Bilgili $\mathrm{H}$, Captug $\mathrm{O}$, et al. Evaluation of a haemostatic agent in rabbits. Afr $\mathrm{J}$ Trad Complement Altern Med 8: 61-65, 2011.

17. Odabas ME, Ertuk M, Cinar C, et al. Cytotoxicity of a new hemostatic agent on human pulp fibroblasts in vitro. Med Oral Patol Oral Cir Bucal 16: 584-587, 2011.

18. Germiyanoglu C, Huri E, Akgul T, et al. In-vivo haemostatic effect of Ankaferd Bloodstopper in rat major renal trauma model: controlled trial of novel haemostatic agent. Eur Urol Suppl 8: 646, 2009.

19. Huri E, Akgul T, Ayyildiz A, et al. Hemostatic role of a folkloric medicinal plant extract in a rat partial nephrectomy model: controlled experimental trial. J Urol 181: 2349-2354, 2009.

20. Huri E, Akgul T, Yucel O, et al. The second step in vitro trial of Ankaferd bloodstopper: comparison with the other hemostatic agents, Glubran 2, Floseal and Celox. Eur Urol Suppl 8: 630, 2009.

21. Isler SC, Demircan S, Cakarer S, et al. Effects of folk medicinal plant extract Ankaferd Blood Stopper (R) on early bone healing. J Appl Oral Sci 18: 409-414, 2010.

22. Karaman K, Celep B, Bostanci EB, et al. Effects of Ankaferd Blood Stopper on Pancreatic Fluid: An in vitro study. Aust NZ J Surgery 80: 946-947, 2010. 
23. Akkoc N, Akcelik M, Haznedaroglu IC, et al. In Vitro Anti-Bacterial Activities of Ankaferd Medicinal Plant Extract. Turkiye Klin Tip Bilim Derg 29: 410-415, 2009

24. Saribas Z, Sener B, Haznedaroglu IC, et al. Antimicrobial activity of Ankaferd Blood Stopper against nosocomial bacterial pathogens. Cent Eur J Med 5: 198202, 2010.

25. Tasdelen Fisgin N, Tanriverdi Cayci Y, Coban AY, et al. Antimicrobial activity of plant extract Ankaferd Blood Stopper. Fitoterapia 80: 48-50, 2009.

26. Kandemir O, Buyukates M, Kandemir NO, et al. Demonstration of the histopathological and immunohistochemical effects of a novel hemostatic agent, ankaferd blood stopper, on vascular tissue in a rat aortic bleeding model. J Cardiothoracic Surg 5: 110-7, 2010.

27. Karakaya K, Ucan HB, Tascilar O, et al. Evaluation of a New Hemostatic Agent Ankaferd Blood Stopper in Experimental Liver Laceration. J Investigative Surg 22: 201-206, 2009.

28. Ozaslan E, Purnak T, Ozyigit G, et al. No prolonged effect of Ankaferd Blood Stopper on chronic radiation proctitis. Endoscopy 42 Suppl 2: E271-2, 2010.

29. Ozaslan E, Purnak T, Yildiz A, et al. The effect of Ankaferd blood stopper on severe radiation colitis. Endoscopy 41 Suppl 2: E321-2, 2009.

30. Ozaslan E, Purnak T, Yildiz A, et al. A new practical alternative for tumoural gastrointestinal bleeding: Ankaferd blood stopper. Dig Liver Dis 42: 594-595, 2010.

31. Trakyali G, Oztoprak MO. Plant Extract Ankaferd Blood Stopper Effect on Bond Strength. Angle Orthodontist 80: 570-574, 2010.

32. Zulfikar OB, Emiroglu HH, Kebudi R. Nasogastric application of topical Ankaferd Blood Stopper for bleeding from primary esophageal adenocarcinoma in a child with disseminated intravascular coagulation. Dig Liver Dis 43: 247-248, 2011.

33. Akgül T, Huri E, Ayyildiz A, et al. Haemostatic and Histopathological Effects of Ankaferd Blood Stopper, on Penile Cavernosal Tissue in Rat. UHOD 19: 159-65, 2009.

34. Germiyanoglu C, Huri E, Akgul T, et al. In vivo Hemostatic Effect of Ankaferd Blood Stopper in Rat Major Renal Trauma Model: Controlled Trial of Novel Hemostatic Agent. UHOD 20: 206-11, 2010.

35. Aktas, A, Er N, Onur MA. Effects of Ankaferd Blood Stopper on Vascular Response in Rat Carotid Artery. UHOD 20: 156-62, 2010.

36. Albayrak M, Aksu S, Celebı H, et al. Striking Promotion of the In Vitro Myeloma Monoclonal Immunoglobulin Aggregation by Ankaferd Hemostat. UHOD 22: 15-22, 2011.
37. Ercetin S, Haznedaroglu IC, Kurt M, et al. Safety and efficacy of Ankaferd BloodStopper in dental surgery and bleeding. UHOD 20: 1-5, 2010.

38. Iynen I, Bozkus F, San I, et al. The hemostatic efficacy of Ankaferd Blood Stopper in adenoidectomy. Int J Pediatr Otorhinolaryngol 75: 1292-1295, 2011.

39. Karaman A, Baskol M, Gursoy S, et al. Endoscopic topical application of ankaferd blood stopper in gastrointestinal bleeding. J Altern Complement Med 18: 65-68, 2012.

40. Teker AM, Korkut AY, Gedikli O, et al. Prospective, controlled clinical trial of Ankaferd Blood Stopper in children undergoing tonsillectomy. Int J Pediatr Otorhinolaryngol 73: 1742-1745, 2009.

41. Yaman E, Görken F, Pinar Erdem A, Sepet E, Aytepe Z. Effects of folk medicinal plant extract Ankaferd Blood Stopper in vital primary molar pulpotomy. Eur Arch Paediatr Dent 13: 197-202, 2012.

42. Meric Teker A, Korkut AY, Kahya V, et al. Prospective, randomized, controlled clinical trial of Ankaferd Blood Stopper in patients with acute anterior epistaxis. Eur Arch Otorhinolaryngol 267: 1377-1381, 2010.

43. Yasar $\mathrm{H}$, Ozkul $\mathrm{H}$. Haemostatic effect of ankaferd blood stopper seen during adenoidectomy. Afr J Trad Complement Altern Med 8: 444-446, 2011.

44. Guler M, Maralcan G, Kul S, et al. The Efficacy of Ankaferd Blood Stopper for the Management of Bleeding Following Total Thyroidectomy. J Investigative Surg 24: 205-210, 2011.

\section{Correspondence}

Dr. Derya KARAKOÇ

Hacettepe Üniversitesi Tıp Fakültesi

Genel Cerrahi Anabilim Dalı

06100 Sihhiye, ANKARA / TURKEY

Tel: (+90.312) 3051730

Fax: (+90.312) 3051614

e-mail: dkarakoc@yahoo.com 